\title{
Pelaksanaan Sistem Pemerintahan Presidensial Dengan Multi Partai Di Indonesia
}

\section{Suparto}

Fakultas Hukum Universitas Islam Riau, Pekanbaru, Indonesia E-mail: suparto@law.uir.ac.id

\begin{tabular}{|c|c|}
\hline Dikirim: 05/09/2021 & Dipublikasi: $31 / 12 / 2021$ \\
\hline Info Artikel & Abstract \\
\hline \multirow[t]{2}{*}{$\begin{array}{l}\text { Keywords: } \\
\text { Government System; } \\
\text { Multiparty; } \\
\text { Parliamentary } \\
\text { Threshold. }\end{array}$} & $\begin{array}{l}\text { The government system in post-reform Indonesia is a presidential system } \\
\text { with many parties. The advantage of this system is that it is more democratic } \\
\text { because many parties are considered to accommodate the wishes and } \\
\text { interests of people from various backgrounds through political parties, } \\
\text { while the weakness is that it is difficult for the ruling party if it is not in the } \\
\text { majority. The purpose of this study was to determine the implementation of } \\
\text { a presidential system of multi-party governance in post-reform Indonesia. } \\
\text { The results of the study are that in a presidential government system with } \\
\text { many parties (multi-party system) such as in Indonesia, it will cause } \\
\text { problems if no political party wins the election with a majority vote, the } \\
\text { President must build a coalition with a number of political parties that have } \\
\text { representatives in the House of Representatives (DPR). DPR). Since the } \\
\text { holding of the } 1999 \text { and } 2004 \text { elections, there have been efforts to simplify } \\
\text { political parties, by reducing the number of election participants through } \\
\text { the electoral threshold and then changing since } 2009 \text { to reducing the } \\
\text { number of political parties that may sit in parliament by using the minimum } \\
\text { threshold requirement (parliamentary threshold). However, this method has } \\
\text { not been successful because there are still relatively many political parties } \\
\text { sitting in parliament, this is due to the parliamentary threshold that is too } \\
\text { small. Ideally, the parliamentary threshold, which was previously } 4 \% \text { in the } \\
2019 \text { election, is raised to 8\% in the } 2024 \text { election. Thus, a strong, effective } \\
\text { and stable presidential government system with only } 4 \text { (four) to } 6 \text { (six) } \\
\text { political parties will be realized. }\end{array}$ \\
\hline & Abstrak \\
\hline $\begin{array}{l}\text { Kata Kunci: } \\
\text { Sistem Pemerintahan; } \\
\text { Multipartai; } \\
\text { Parliamentary } \\
\text { Threshold. }\end{array}$ & $\begin{array}{l}\text { Sistem pemerintahan di Indonesia pasca reformasi adalah system } \\
\text { presidensial dengan banyak partai. System seperti ini kelebihannya adalah } \\
\text { lebih demokratis karena dengan banyaknya partai dianggap lebih banyak } \\
\text { mengakomodir keinginan dan kepentingan masyarakat dari berbagai latar } \\
\text { belakang melalui wadah partai politik, sedangkan kelemahannya adalah } \\
\text { sulit bagi partai penguasa apabila ia tidak mayoritas. Tujuan dari penelitian } \\
\text { ini adalah untuk mengetahui pelaksanaan sistem pemerintahan } \\
\text { presidensial dengan multipartai di Indonesia pasca reformasi. Hasil } \\
\text { penelitian adalah dalam sistem pemerintahan presidensial dengan banyak } \\
\text { partai (multy party system) seperti di Indonesia, akan menimbulkan } \\
\text { persoalan kalau tidak ada partai politik yang memenangkan pemilu dengan } \\
\text { suara mayoritas, Presiden harus membangun koalisi dengan sejumlah partai }\end{array}$ \\
\hline
\end{tabular}


DOI:

10.47268/sasi.v27i4.600

politik yang mempunyai wakil di Dewan Perwakilan Rakyat (DPR). Sejak penyelenggaraan pemilu tahun 1999 dan 2004 telah ada upaya penyederhanaan partai politik, dengan mengurangi jumlah peserta pemilu melalui electoral threshold dan kemudian berubah sejak tahun 2009 menjadi pengurangan jumlah partai politik yang boleh duduk di parlemen dengan menggunakan syarat ambang batas minimal (parliamentary threshold). Namun demikian cara tersebut belum berhasil karena partai politik yang duduk di parlemen masih relative banyak hal ini disebabkan angka parliamentary threshold yang terlalu kecil. Idealnya angka parliamentary threshold yang sebelumnya $4 \%$ pada pemilu 2019 dinaikkan menjadi $8 \%$ pada pemilu tahun 2024. Dengan demikian, sistem pemerintahan presidensial yang kuat, efektif dan stabil dengan hanya 4 (empat) sampai 6 (enam) partai politik akan terealisir.

\section{A. PENDAHULUAN}

Bila dilihat sejarah kerjasama antar partai politik di Indonesia, termasuk di dalamnya ketika sistem pemerintahan berparlemen masa 1949-1959 ataupun ketika masa reformasi (1999-2014) keterikatan koalisi memang amat rapuh. Banyak pengamat yang menyatakan keadaan ini dinilai sebagai pelaksanaan demokrasi yang kekanak-kanakan dan karenanya sangat pantas kalau partai politik sebaiknya dikubur saja atau menurut Alfian sebagai demokrasi yang sarat konflik dan sukar menemukan titik-titik konsensus. Demikian juga ketika masa reformasi adanya koalisi poros tengah, koalisi kebangsaan dan koalisi kerakyatan, koalisi sekretariat bersama gabungan partai 2009-2014, yang sampai batas-batas tertentu selalu menunjukkan bahwa tradisi koalisi partai politik di Indonesia sangatlah longgar dan sampai batas-batas tertentu lainnya dikatakan sebagai masa yang belum matang untuk mempraktikkan kedewasaan berkoalisi. ${ }^{1}$

Pengaturan mengenai partai politik mengambil satu prinsip yaitu penghormatan atas kebebasan berkumpul, berserikat atau berasosiasi. Oleh karena prinsip ini, maka tidak akan ada ketentuan dari undang-undang untuk membatasi jumlah pendirian suatu partai. ${ }^{2}$ Demokrasi telah dianggap sebagai sebuah instrumen penting dalam menjalankan sebuah konsepsi negara yang ideal untuk menjawab persoalan tentang penegakan kekuasaan rakyat. ${ }^{3}$ Meskipun Indonesia saat ini menganut presidensialisme yang telah mengalami purifikasi, ternyata praktiknya masih lebih berat ke sistem parlementer seperti halnya masa sebelum amandemen konstitusi. Contohnya, saat ini hanya untuk menunjuk seorang Duta Besar, Presiden harus mendapatkan persetujuan DPR. Padahal di seluruh dunia, hal itu hanya terjadi di Indonesia. Fenomena ini menunjukkan sebuah dilema sekaligus paradoks kekuasaan Presiden dalam sistem presidensial. Fenomena ini telah memperkuat tesis bahwa sistem presidensial yang diterapkan di atas struktur politik multipartai diragukan dapat mendorong demokratisasi, dan diyakini akan cenderung melahirkan konflik antara lembaga Presiden dan parlemen, yang akan menghadirkan demokrasi yang tidak stabil.

Menurut Jimly Asshiddiqie sebagaimana dikutip olehPataniari Siahaan,di dalam teori sistem pemerintahan ini akan dijelaskan konsep-konsep kekuasaan lembaga negara serta letak kekuasaan pembentukan undang-undang dalam setiap sistem pemerintahan. Pengaturan pembentukan mengenai undang-undang termasuk instrumen pendukungnya berada dalam lingkup sistem pemerintahan. Oleh sebab itu pembahasan tentang perubahan kekuasaan

Abadi, H. (2014). Presidential Threshold Sebagai Instrumen Proteksi, Mahkamah, 6 (1) : 29-36, h.30.

Abadi, H. (2011). Perubahan Konstitusi dan Implikasinya Pada Politik Hukum Kepartaian di Indonesia, Mahkamah, 3 (2): 12-24, h. 22.

3 Chaidir, E. \& Suparto, (2017). Implikasi Putusan Mahkamah Konstitusi Tentang Pemilu Serentak Terhadap Pencalonan Presiden dan Wakil Presiden Pada Pemilihan Umum Tahun 2019, UIR Law Review, 1 (1): 1-12, DOI : https ://doi.org/10.25299/url.2017.1.01.561

$$
\text { 517|SASI Vol. } 27 \text { No.4, Oktober - Desember } 2021
$$


membentuk undang-undang ini tidak dapat dilepaskan dari teori sistem pemerintahan yang menjelaskan logika kekuasaan/fungsi legislasi dan berbagai teknis prosedurnya. ${ }^{4}$

Walaupun telah cukup banyak upaya para ahli perbandingan politik untuk mengidentifikasi pengaruh variabel-variabel non-institusional seperti faktor sejarah, politik, perkembangan ekonomi, dan kultural suatu negara bagi stabilitas demokrasi, tetapi relatif masih terbatas studi yang memfokuskan diri pada pengaruh faktor kepemimpinan. Arend Lijphart misalnya, mengingatkan faktor perkembangan ekonomi suatu negara dan tingkat pluralitas masyarakat turut menentukan stabilitas demokrasi, baik di bawah sistem presidensial maupun sistem parlementer.

Namun demikian, temuan studi ini menunjukkan bahwa personalitas dan gaya kepemimpinan Presiden menjadi variabel independen yang penting bukan hanya karena dalam konteks presidensialisme jabatan Presiden merupakan lokus kekuasaan pemerintahan, melainkan juga karena pola kepemimpinan Presiden cenderung menentukan realitas relasi Presiden dan DPR serta sebagai konsekuensi logisnya-efektivitas sistem presidensial yang dihasilkannya. $^{5}$

Dalam pemerintahan presidensiil kekuasaan eksekutif dengan kekuasaan legislatif diartikan sebagai bahwa kekuasaan eksekutif itu dipegang oleh suatu badan atau organ yang di dalam menjalankan tugas eksekutifnya tidak bertanggungjawab kepada badan perwakilan rakyat. Susunan dari badan eksekutif terdiri atas seorang Presiden sebagai kepala pemerintahan, didampingi oleh seorang Wakil Presiden. Dalam menjalankan tugasnya, Presiden dibantu oleh para menteri. Secara otomatis, menteri tersebut bertanggungjawab kepada Presiden serta diangkat dan diberhentikan oleh Presiden. Badan perwakilan rakyat tidak dapat memberhentikan seorang atau beberapa menteri, meskipun badan perwakilan rakyat tidak menyetujui kebijakan-kebijakan yang dikeluarkan oleh menteri yang bersangkutan. Dalam konteks lain, antara Presiden dan Wakil Presiden sebenarnya merupakan "satu paket", jadi apapun tindakan Wakil Presiden sebenarnya juga mewakili Presiden. ${ }^{6}$

\section{B. PEMBAHASAN}

\section{Pelaksanaan Sistem Pemerintahan Presidensial Dengan Multi Partai Di Indonesia Pasca Reformasi}

Seperti dikemukakan Mainwaring, Cheibub, Gunther, Linz, dan juga Lijphart, salah satu problematik sistem demokrasi presidensial adalah jika ia dikombinasikan dengan sistem multipartai. Presidensialisme dan sistem multipartai bukan hanya merupakan kombinasi yang sulit, melainkan juga membuka peluang terjadinya kelumpuhan atau deadlock dalam relasi eksekutif-legislatif yang kemudian berdampak pada instabilitas demokrasi presidensial. Ironisnya, fenomena itulah yang terjadi di Indonesia pasca Soeharto, sistem presidensial berlangsung bersamaan dengan sistem multipartai. ${ }^{7}$

Menurut penulis salah satu kesulitan sistem multipartai dalam sistem pemerintahan presidensial adalah jika partai pemenang pemilu adalah partai minoritas di DPR. Seperti diketahui bersama bahwa pemilihan umum Presiden secara langsung, faktor figur atau calon Presiden itu sendiri terkadang lebih besar pengaruhnya dari pada partai politik pengusung calon Presiden itu sendiri, artinya belum tentu calon Presiden yang diusung oleh partai atau gabungan partai-partai yang perolehan suaranya sangat signifikan atau besar secara otomatis pasti dipilih oleh konstituen atau memenangkan kontestasi (persaingan) tersebut. Ketika Presiden terpilih

4 Siahaan, P. (2012). Politik Hukum Pembentukan Undang - Undang Pasca Amandemen UUD 1945, Jakarta: Konstitusi Press, h. 18-19.

5 Haris, S. (2014). Praktik Parlementer Demokrasi Presidensial Indonesia, Yogyakarta: Andi Offset, h. 244-245.

6 Chaidir, E. \& Fahmi, S. (2010). Hukum Perbandingan Konstitusi, Yogyakarta: Total Media, h.161.

7 Haris, S. (2014). Praktik Parlementer...Op.Cit., h. 36.

$$
\text { 518|SASI Vol. } 27 \text { No.4, Oktober - Desember } 2021
$$


berasal dari partai minoritas, koalisi memang menjadi keharusan dan ini merupakan titik awal terjadinya proses bargaining politik.

Secara teoritis, koalisi partai sebenarnya lebih lazim dalam konteks sistem parlementer dengan sistem multipartai karena koalisi diperlukan untuk membentuk pemerintahan yang kuat ketika hasil pemilu parlemen begitu fragmentatif. ${ }^{8}$ Oleh karena itu, koalisi partai dalam konteks sistem presidensial dan sistem parlementer mempunyai tiga perbedaan. Pertama,dalam sistem parlementer partai-partai menentukan atau memilih anggota kabinet dan perdana menteri, sehingga mereka (partai-partai) tetap bertanggung jawab atas dukungannya terhadap pemerintah. Sedangkan dalam sistem presidensial, Presiden memilih sendiri anggota kabinetnya termasuk yang berasal dari partai sehingga tidak ada komitmen dukungan partaipartai terhadap Presiden. Kedua, berlawanan dengan sistem parlementer, dalam sistem presidensial tidak ada jaminan bahwa partai akan mendukung kebijakan Presiden meskipun Presiden mengakomodasi secara individual tokoh-tokoh partai sebagai anggota kabinet. Ketiga, sebagai konsekuensi logisnya, dalam sistem presidensial koalisi semacam itu cenderung mendorong partai-partai untuk lebih mudah keluar atau meninggalkan koalisi dibandingkan sistem parlementer.

Walaupun konsep koalisi secara teoritis lebih lazim dalam konteks sistem parlementer ketimbang sistem presidensial, namun ketika sistem presidensial tersebut berbasiskan sistem multipartai, koalisi antara partai merupakan realitas politik yang tak terhindarkan. ${ }^{9}$ Oleh karena itu, koalisi partai dalam konteks presidensialisme yang dikombinasikan sistem multipartai adalah salah satu problematik institusional yang melekat ketika pilihan tak terhindarkan tersebut harus diambil oleh Presiden terpilih dalam rangka memperluas basis dukungannya di parlemen. Problematik institusional tersebut menjadi lebih kompleks lagi jika realitas koalisi tidak didasarkan pada konsensus minimum diantara pihak-pihak yang berkoalisi, sehingga berpotensi bubar di tengah jalan. ${ }^{10}$ Dalam perjalanan sejarah Republik Indonesia, memang belum ada koalisi pemerintahan dalam sistem pemerintahan presidensial yang bubar di tengah jalan, namun disharmoni hubungan Presiden dan Wakil Presiden pernah terjadi di Pemerintahan SBY-Kalla.

Ada beberapa faktor yang mendorong terjadinya disharmoni dan rivalitas terselubung dalam relasi Presiden Yudhoyono dan Wakil Presiden Jusuf Kalla. Pertama, koalisi yang dibangun adalah koalisi pragmatis, sehingga sangat rapuh. Kedua, posisi politik Kalla lebih kuat daripada Yudhoyono di DPR (Presiden minoritas dan Wakil Presiden mayoritas). Disharmoni ini pada akhirnya akan memengaruhi soliditas dan kekompakan kabinet. ${ }^{11}$

Disharmoni hubungan Presiden secara terselubung ini terlihat dari praktik keseharian dalam pemerintahan. Sekadar contoh, ketika sedang berada di Amerika Serikat untuk menghadiri Konferensi Tingkat Tinggi Perserikatan Bangsa-Bangsa, Presiden Yudhoyono mengadakan rapat kabinet melalui telekonferensi. Rapat jarak jauh ini dipimpin Presiden Yudhoyono dari Amerika Serikat sedangkan para menteri berada di Jakarta.

Ada dua kejanggalan, jika dicermati secara politik dalam rapat kabinet jarak jauh ini. Pertama, sebelum berangkat ke Amerika Serikat, Presiden Yudhoyono sudah menandatangani surat resmi yang menugasi Wakil Presiden Jusuf Kalla untuk menjalankan tugas sehari-hari pemerintahan selama Presiden di luar negeri. Salah satu tugas yang dimaksud dalam Keputusan Presiden Nomor 26 Tahun 2005 itu adalah memimpin kabinet. Meskipun sudah mengeluarkan

8 Busroh, F.F. (2017). Reformulasi Penetapan Electoral Threshold Dalam Sistem Kepartaian di Indonesia, Lex Librum, 3 (2) : 513-524, h. 520, DOI : http : //doi.org/10.5281/zenodo.1257770

9 Ibid., h.156.

10 Saraswati, R. (2012). Desain Sistem Pemerintahan Presidensial Yang Efektif, Masalah Masalah Hukum, 41 (1) : 137-143, h. 140, DOI : 10.14710/mmh.41.1.2012.137-143

11 Yudha AR, H. (2010). Presidensialisme Setengah Hati Dari Dilema Ke Kompromi, Jakarta: Gramedia Pustaka Utama, h. 145

$$
\text { 519|SASI Vo1. } 27 \text { No.4, Oktober - Desember } 2021
$$


Keppres untuk menugasi Wakil Presiden Jusuf Kalla memimpin rapat kabinet, ternyata Presiden Yudhoyono justru memimpin rapat kabinet dari jarak jauh. Ini bisa ditafsirkan salah satu bentuk ketidakpercayaan Presiden terhadap Wakil Presiden.

Kedua, Wakil Presiden Jusuf Kalla justru sering tidak menghadiri rapat kabinet melalui telekonferensi tersebut. Padahal sangat jelas dalam aturan politik ketatanegaraan, setiap rapat kabinet yang dipimpin Presiden idealnya harus dihadiri Wakil Presiden. Jika dicermati, fenomena ini menguatkan sinyalemen adanya hubungan yang kurang harmonis antara keduanya. ${ }^{12}$

Persoalan lain yang merupakan dampak dari kombinasi presidensialisme dan sistem multipartai adalah lemahnya disiplin partai-partai dalam mempertahankan sikap dan prinsip politik mereka. Problematik lemahnya disiplin partai dalam sistem presidensial ini sebenarnya sudah diingatkan oleh para ahli perbandingan politik sebagai konsekuensi logis yang tidak terelakkan seperti dialami negara-negara dengan sistem presidensial di Amerika Latin dan juga Filipina. $^{13}$

Setelah menolak pidato pertanggungjawaban Presiden BJ. Habibie melalui pemungutan suara, Majelis Permusyawaratan Rakyat hasil Pemilu 1999 mengangkat Abdurrahman Wahid sebagai Presiden yang baru dan Megawati Soekarnoputri sebagai Wakil Presiden. Meskipun Pemilu 1999 dimenangkan oleh PDIP yang dipimpin Megawati, koalisi longgar partai-partai berbasis Islam, Poros Tengah, berhasil mengganjal Megawati dan memuluskan proses terpilihnya deklarator PKB Abdurrahman Wahid sebagai Presiden.

Selama tiga bulan pertama masa pemerintahannya, duet Abdurrahman-Mega dipuji sebagai pasangan dwi-tunggal yang ideal karena dianggap merefleksikan perpaduan dua kekuatan besar bangsa Indonesia, yaitu Islam yang direpresentasikan Abdurrahman Wahid dan golongan nasionalis yang diwakili oleh sosok Megawati. ${ }^{14}$

Namun secara berangsur kepercayaan dan legitimasi pemerintahan demokratis produk Pemilu 1999 tersebut makin merosot menyusul munculnya berbagai wacana dan kebijakan Presiden yang dianggap kontroversial serta terungkapnya kasus penyalahgunaan dana Yanatera Bulog dan dana sumbangan Sultan Brunei. Puncak merosotnya kepercayaan dan legitimasi terhadap Abdurrahman Wahid itu muncul dalam bentuk konflik Presiden dengan DPR yang akhirnya bermuara pada keluarnya memorandum pertama dan kedua DPR serta keputusan dewan untuk merekomendasikan Sidang Istimewa MPR sebagai forum untuk meminta pertanggungjawaban Presiden yang dijadwalkan mulai berlangsung pada 1 Agustus 2001, yakni tepat dua bulan sesudah DPR mengirim memorandum kedua tanggal 30 Mei 2001.

Konflik antara Presiden Wahid dan DPR memuncak ketika di tengah ketegangan politik yang tinggi menyusul kebijakan kontroversial Presiden Wahid menonaktifkan Kapolri Jenderal Bimantoro serta pengangkatan Wakapolri Chaeruddin Ismail sebagai pejabat sementara Kapolri tanpa persetujuan DPR, Abdurrahman Wahid justru mengeluarkan Maklumat Presiden untuk membubarkan DPR dan MPR, menetapkan percepatan pelaksanaan pemilu dan membekukan Partai Golkar. Atas dasar keluarnya maklumat atau dekrit tersebut, fraksi-fraksi MPR (minus fraksi PKB dan PDKB) kemudian memutuskan mempercepat pelaksanaan sidang istimewa yang akhirnya menetapkan pemberhentian Abdurrahman Wahid sebagai Presiden karena dinilai melakukan pelanggaran konstitusi. Pada sidang yang sama, MPR mengangkat Wapres Megawati menjadi Presiden dan Ketua Umum PPP Hamzah Haz sebagai Wakil Presiden. ${ }^{15}$

Pada era Presiden Wahid yang keterpilihannya didukung oleh koalisi longgar partai-partai

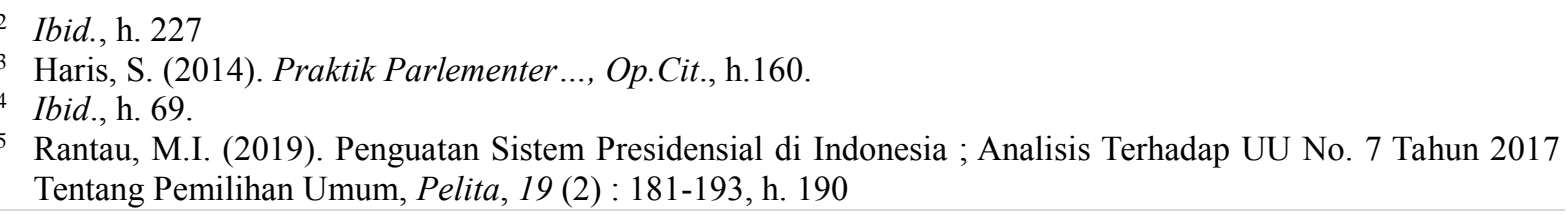


berbasis Islam Poros Tengah inisiatif untuk mendorong manta Ketua Umum PBNU itu menjadi calon Presiden justru datang dari Amien Rais selaku pemimpin informal Poros Tengah. Tampaknya Presiden Wahid sadar akan hal itu sehingga Kabinet Persatuan Nasional yang dibentuknya tidak hanya mengakomodasi para tokoh partai-partai dari lingkungan Poros Tengah, melainkan juga dari PDIP yang dipimpin Wapres Megawati dan dari Golkar yang turut mendukung keterpilihannya. Namun problematiknya, tidak ada basis kesepakatan politik yang mengikat partai-partai yang berkoalisi, baik ketika pencalonan Presiden menjelang SU MPR 1999 maupun menjelang pembentukan kabinet. Ketiadaan kesepakatan politik itu antara lain melatarbelakangi mengapa Presiden Wahid begitu mudah dan tanpa beban mencopot menteri dari partai yang memiliki basis politik cukup besar di parlemen seperti dialami oleh Hamzah Haz (PPP) dan Laksamana Sukardi (PDIP). ${ }^{16}$

Sebaliknya, ketiadaan konsensus politik itu juga menjelaskan mengapa partai-partai pengusung Wahid akhirnya harus berkhianat mendongkel cucu pendiri NU KH. Hasyim Asy'ary itu dari kursi kepresidenan. Selain itu, dalam kasus Presiden Wahid jelas sekali terlihat bahwa Presiden tidak berupaya memelihara dukungan politik dari partai-partai di DPR, sehingga dengan mudah mengundang protes keraspartai-partai ketika menteri-menteri dari partai yang bersangkutan di copot dari jabatannya tanpa alasan yang jelas. ${ }^{17}$

Menurut pendapat penulis terpilihnya Abdurrahman Wahid atau Gus Dur sebagai Presiden pasca hasil pemilihan umum legislatif tahun 1999 merupakan hal yang menjadi fenomenal. Sebagaimana diketahui bahwa PDIP merupakan partai pemenang pemilu dengan perolehan suara $(33,74 \%$ walaupun bukan mayoritas), tentunya Megawati mempunyai chance yang lebih besar untuk dipilih menjadi Presiden, walaupun sistem pemilihan Presiden pada waktu itu masih dilakukan oleh MPR. Namun karena tingginya tingkat kecurigaan kelompok Islam dalam hal ini koalisi Poros Tengah yang digagas oleh Zarkasih Noer, salah seorang Ketua DPP PPP dan Amien Rais selaku pemimpin informal Poros Tengah, ${ }^{18}$ terhadap kelompokNasionalis-Sekuler yang dipimpin Megawati, dimana salah satu kekhawatiran tersebut adalah jika Megawati menjadi Presiden maka akan terjadi pertumpahan darah, maka memilih GusDur merupakan jalan tengah untuk menjaga integritas bangsa ini. Dalam sistem pemerintahan Presidensial, pengangkatan maupun pemberhentian menteri-menteri memang merupakan hak prerogatif Presiden. Namun ketika sistem presidensial tersebut dipadukan dengan sistem multipartai, keterlibatan Wakil Presiden dan partai-partai pendukung lainnya dalam pengambilan keputusan-keputusan penting sudah seharusnya dilibatkan. Presiden tidak seharusnya mengambil tindakan sendiri terkait keputusan-keputusan penting, terlebih lagi Presiden tersebut berasal dari partai minoritas. Jika Presiden Wahid dapat menjaga pola komunikasi yang baik serta mengakomodir semua kepentingan partai-partai pendukung, indikasi penyalahgunaan dana, blunder politik dan tindakan inkonstitusionalitas yang dilakukannya, tentunya dapat diselesaikan tanpa bermuara kepada proses pemakzulannya.

Bagi kehidupan kepartaian di Indonesia, amat tebalnya ikatan kepada ideologi lebih mempersukar kerjasama diantara elit daripada mendorong penciptaan konsensus. ${ }^{19}$ Meskipun pemerintahan Megawati lahir dari kekecewaan DPR terhadap Presiden Wahid, namun tetap tidak mengubah pola relasi Presiden-DPR kendati situasi konfrontatif seperti era sebelumnya tidak terjadi lagi. Sebagai ketua umum partai pemenang Pemilu 1999 dengan jumlah kursi terbesar di DPR, Presiden Megawati tidak sepenuhnya dapat mengendalikan DPR karena kekuatan PDIP hanya sekitar sepertiga (153 kursi) dari total keseluruhan anggota Dewan (500

\footnotetext{
16 Ibid., h.158.

17 Romli, L. (2011). Reformasi Partai Politik dan Sistem Kepartaian di Indonesia, Politica, 2 (2) : 199-220, h. 200

18 Efriza, (2019). Penguatan Sistem Presidensial Dalam Pemilu Serentak 2019, Jurnal Penelitian Politik, 16 (1) : 1-15, h. 13

19 Sanit, A. (2012). Sistem Politik Indonesia, Jakarta: Rajawali Pers, h. 31.
}

$$
\text { 521|SASI Vol. } 27 \text { No.4, Oktober - Desember } 2021
$$


kursi $)^{20}$. Oleh karena itu, dukungan partai-partai lain diperlukan agar ada jaminan bahwa kebijakan-kebijakan pemerintah tidak mengalami ganjalan di DPR. Walaupun demikian, selama sekitar 1186 hari masa pemerintahannya, kebijakan Presiden Megawati beberapa kali digugat oleh DPR melalui usulan penggunaan hak interpelasi, antara lain dalam kasus lenyapnya kepemilikan Indonesia atas pulau Sipadan dan Ligitan, kunjungan Megawati ke Timor Leste, dan kasus dana bantuan sebesar 30 miliar bagi asramaTNI/Polri.

Kecuali interpelasi DPR tentang lepasnya pulau Sipadan dan Ligitan yang didukung oleh semua fraksi di dewan kecuali PDIP, upaya penggunaan hak interpelasi lainnya gagal karena partai Golkar di bawah kepemimpinan Akbar Tandjung yang sekaligus juga Ketua DPR hampir selalu menolak usulan penggunaan hak interpelasi untuk masalah-masalah yang tidak begitu krusial. Akbar sendiri mengakui bahwa hubungan antara partai Golkar dan pemerintahan Megawati secara umum lebih baik dibandingkan dengan pemerintahan Abdurrahman Wahid. Namun demikian, ada juga yang mempertanyakan kurang berminatnya partai Golkar mendukung usulan interpelasi kasus dana bantuan bagi asrama TNI/Polri. Partai yang dipimpin Megawati sendiri mencurigai bahwa, baik sikap lunak Akbar Tandjung dalam soal interpelasi dana bantuan bagi asrama TNI/Polri, maupun sikap keras anggota F-PG dalam usulan interpelasi kunjungan Megawati ke Timor Leste, berkaitan dengan upaya Golkar mencegah pembentukan Panitia Khusus (pansus) kasus dana nonbujeter Bulog yang melibatkan Akbar Tandjung. ${ }^{21}$

Di luar upaya penggunaan hak interpelasi, riak-riak konflik dalam relasi Presiden-DPR pada era Megawati juga sempat terjadi ketika 137 orang Anggota Dewan dari lintas fraksi mencoba menggunakan hak angket dalam kasus divestasi atau penjualan PT. Indosat, sebuah Badan Usaha Milik Negara yang sebenarnya secara ekonomi merupakan aset besar bangsa Indonesia.

Sikap politik partai Golkar pada era Presiden Megawati ini tidak hanya mengundang reaksi partai-partai lain, melainkan juga menimbulkan kekecewaan internal Golkar, serta sebagian unsur PDIP yang kecewa atas kepemimpinan Megawati. Salah satu bentuk reaksi itu adalah pembentukan Kaukus Penyelamatan Bangsa yang bersifat lintas fraksi dan bahkan melibatkan Menteri Negara/Kepala Bappenas Kwik Kian Gie dari PDIP. Selain reaksi internal DPR, kekecewaan terhadap pemerintahan Megawati juga mengundang reaksi berbagai kelompok oposisi di kalangan aktivis LSM, mahasiswa, dan sejumlah tokoh seperti Abdurrahman Wahid serta beberapa pensiunan jenderal dengan menggulirkan wacana pembentukan Presidium untuk menggantikan pemerintahan Megawati. ${ }^{22}$

Kalangan aktivis LSM, buruh (FNPBI), PRD dan Front Aksi Mahasiswa UI bahkan kemudian membentuk koalisi nasional dengan agenda pokok menurunkan pasangan MegawatiHamzah Haz dari jabatan Presiden dan Wakil Presiden. Meskipun demikian, secara umum relasi Presiden-DPR relatif lebih kondusif, terutama karena pengalaman traumatik pada era Presiden Wahid membuat partai-partai politik di DPR menahan diri sehingga Presiden Megawati bisa bertahan sampai akhir masa jabatannya pada 20 Oktober $2004 .^{23}$

Menurut penulis tidak ada jaminan di dalam politik, partai pemenang pemilu, walaupun menguasai sepertiga kursi parlemen secara otomatis lebih mudah dalam mengendalikan parlemen dan pemerintahan. Ketika Presiden salah dalam membuat kebijakan sehingga merugikan negara, kontrol DPR melalui hak interpelasi, angket serta menyatakan pendapat

20 Dari total 500 anggota DPR, 462 anggota dipilih melalui pemilihan umum, sedangkan 38 anggota lainnya merupakan anggota TNI/Polri yang diangkat.

21 Haris, S. (2014). Praktik Parlementer..., Op.Cit., h. 89.

22 Arman, Z. (2018). Tinjauan Terhadap Sistem Multi Partai dalam Sistem Pemerintahan Presidensial di Indonesia Pada Era Reformasi, Cahaya Keadilan, 6 (1) : 23-40, h. 35, DOI: https : //doi.org/10.33884/jck.v6i1.875

23 Al Arif, M. Y. (2015). Anomali Sistem Pemerintahan Presidensial Pasca Amandemen UUD 1945, Ius Quia Ius Tum, 22 (2) : 238-254, h. 250, DOI : 10.20885/iustum.vol22.iss2.art4

$$
\text { 522|S A I Vol. } 27 \text { No.4, Oktober - Desember } 2021
$$


merupakan suatu keharusan dalam rangka check and balance. Adagium yang menyatakan dalam politik tidak ada musuh yang abadi, yang ada hanyalah kepentingan yang sejati memang benar adanya. Bagaimana mungkin partai Golkar yangnotabene sebagai partai oposisi pada waktu itu akan mendukung penggunaan hak angket dalam kasus divestasi atau penjualan PT. Indosat oleh pemerintah,di sisi lain Ketua Umum Partai Golkar Akbar Tandjung juga diduga terlibat dalam penyalahgunaan dana nonbujeter. ${ }^{24}$ Ketika pihak pemerintah salah dalam membuat kebijakan dan partai opisisi terlibat dalam dosa masa lalu, kompromi politik merupakan solusi yang tidak terhindarkan.

Problematik kombinasi antara presidensialisme dan sistem multipartai tak hanya berlangsung pada era Presiden Wahid dan Presiden Megawati, melainkan juga pada era Presiden Yudhoyono. Fragmentasi dan polarisasi kekuatan partai di DPR hasil Pemilu 1999 dan 2004 menggambarkan dengan jelas potensi problematik sistem dan praktik presidensialisme pasca Soeharto. Pemilu 1999 yang diikuti 48 partai ternyata menghasilkan 21 partai politik efektif di DPR yang kemudian mengelompok ke dalam 10 fraksi. Sedangkan pemilu 2004 yang diikuti 24 partai menghasilkan 16 partai yang juga mengelompok ke dalam 10 fraksi politik. Lebih jauh lagi, tidak satu pun partai politik yang berhasil menjadi kekuatan mayoritas di DPR, sehingga tarik menarik antara partai di parlemen dalam interaksi dengan Presiden cenderung menghasilkan pola relasi yang kurang mendukung terciptanya stabilitas dan efektif demokrasi presidensial. $^{25}$

Dengan sistem multipartai, Presiden harus membangun koalisi dengan sejumlah partai politik di DPR. Keharusan itu seperti menjadi keniscayaan jika Presiden berasal dari kekuatan minoritas di DPR. Pengalaman bulan-bulan pertama masa jabatan pertama Presiden Susilo Bambang Yudhoyono (2004-2009) membuktikan betapa kuatnya perlawanan terbuka mayoritas partai politik di DPR. Tidak jarang keluar ancaman untuk menggagalkan semua agenda Presiden yang bersentuhan dengan DPR. Dengan fakta seperti itu, tanpa koalisi, Presiden akan kesulitan berhadapan dengan DPR termasuk dalam fungsi legislasi. Singkatnya, Presiden Yudhoyono terpenjara oleh sistem multipartai. ${ }^{26}$

Pendapat penulis koalisi seharusnya tidak hanya terjadi di kabinet, melainkan juga di parlemen. Proses menuju koalisi dengan partai-partai tersebut biasanya melalui proses yang panjang dan tawar menawar politik pasti tidak dapat dihindari karena berbicara politik tentunya berbicara kepentingan. Ketika koalisi terjalin, sudah dipastikan akan terjadi pembagian kekuasaan (power sharing).

Presiden Susilo Bambang Yudhoyono dan Wakil Presiden Jusuf Kalla adalah PresidenWapres pertama dalam sejarah Indonesia yang dipilih secara langsung oleh rakyat pada Pemilu 2004. Konsekuensi logis dari mekanisme pemilihan langsung pasangan Presiden-Wapres adalah kuatnya legitimasi politik lembaga kepresidenan dibandingkan institusi kepresidenan hasil pemilihan secara tidak langsung melalui MPR.

Namun demikian, secara objektif realitas politik hasil pemilu 2004 tidak mendukung hal ini. Partai Demokrat (PD) yang menjadi basis politik Presiden Yudhoyono sendiri hanya memiliki 55 kursi di DPR, sedangkan tiga partai politik yang turut mengusungnya, yakni PKS, PBB, PKPI masing-masing hanya memperoleh 45 kursi, 11 kursi, satu kursi di lembaga legislatif tersebut. Dengan demikian, secara keseluruhan koalisi partai pengusung pasangan Yudhoyono-Kalla hanya menguasai 113 kursi atau sekitar 20,5\% dari 550 kursi di DPR, suatu jumlah yang jelas tidak cukup memadai untuk menggalang dukungan dewan terhadap

${ }^{24}$ Partono (2008). Sistem Multi Partai Presidensial dan Persoalan Efektifitas Pemerintah, Legislasi Indonesia, 5 (1) : $13-28$, h. 25

25 Haris, S. (2014). Praktik Parlementer ...Op. Cit, h. 36

26 Isra, S. (2010). Pergeseran Fungsi Legislasi; Menguatnya Model Legislasi Parlementer dalam Sistem Presidensial Indonesia, Jakarta : Rajawali Pers, h. 8-9. 
kebijakan-kebijakan pemerintah.

Tampaknya sadar akan realitas politik pragmentatif demikian maka Presiden Yudhoyono menyusun Kabinet Indonesia Bersatu tidak semata-mata berdasarkan kapabilitas dan keahlian para calon menteri, melainkan juga atas dasar pertimbangan basis politik atau asal partai sebagian calon menterinya. Selain didukung PD, PBB, PKS dan PKPI, Kabinet Indonesia Bersatu didukung pula oleh empat partai lainnya, yakni Golkar (128 kursi), PPP (58 kursi), PAN (53 kursi) dan PKB (52 kursi), sehingga secara teoritis pemerintahan Yudhoyono sekurang-kurangnya didukung mayoritas (403 kursi atau lebih dari $70 \%$ dari 550 kursi) kekuatan partai di DPR. ${ }^{27}$

Menurut Penulis memang sangat sulit untuk menerapkan koalisi yang permanen ${ }^{28}$ karena koalisi yang permanen biasanya dapat dijalankan apabila ada kesamaan ideologis diantara partai-partai yang tergabung dalam koalisi tersebut. Berdasarkan fatsun politik, idealnya partaipartai yang tergabung dalam koalisi harus mendukung secara penuh segala kebijakan yang dibuat oleh Presiden selaku pimpinan koalisi. Tetapi realitanya, koalisi tetaplah koalisi, ketika kebijakan yang dibuat oleh Presiden sebagai pimpinan koalisi dianggap tidak populis, tidak pro terhadap rakyat kecil (misalnya terkait dengan kenaikan harga Bahan Bakar Minyak), tidak jarang partai-partai yang tergabung dalam koalisi tersebut ikut mengkritisi dan bahkan menjadi pihak oposisi karena khawatir akan kehilangan suara dari rakyat.Memang kritik tersebut tidak sampai berimplikasi bubarnya koalisi tetapi menunjukkan koalisi yang dilakukan adalah koalisi setengah hati.Seharusnya ketika sudah tergabung dalam koalisi, secara etika politik tentunya harus mendukung penuh serta turut mengamankan semua kebijakan yang dibuat oleh pemerintah, walaupun kebijakan tersebut dianggap tidak populis, jadi tidak perlu ada oposisi di dalam koalisi. Inilah dilema yang dihadapi ketika koalisi yang terjalin bukan karena adanya kesamaan ideologis, akibatnya bersifat pragmatis, transaksional dan sesaat.

Pemilihan Presiden 2009 hanya diikuti oleh tiga pasang calon. Mereka adalah pasangan Megawati Soekarnoputri - Prabowo Subianto, Susilo Bambang Yudhoyono (SBY)-Boediono dan Jusuf Kalla (JK)-Wiranto. Megawati-Prabowo didukung oleh PDIP dan Gerindra serta sejumlah partai kecil. SBY-Boediono didukung oleh Partai Demokrat, PKS, PAN, PPP, PKB dan banyak partai kecil. Sedangkan JK-Wiranto didukung oleh Golkar dan Hanura. Di dalam pilpres ini, pasangan SBY-Boediono memperoleh suara meyakinkan, sehingga memenangkan pemilihan cukup hanya satu putaran saja. ${ }^{29}$ Pada masa Presiden SBY yang kedua, walaupun menguasai mayoritas dukungan partai politik yang ada di parlemen, namun pemerintahan SBYBoediono terus dirongrong oleh anggota DPR yang notabene berasal dari partai politik koalisi pemerintahan, dan kasus yang paling menyita perhatian adalah kasus Bank Century.

Pemilihan umum Presiden dan Wakil Presiden Republik Indonesia Tahun 2014 dilaksanakan pada tanggal 9 Juli 2014 untuk memilih Presiden dan Wakil Presiden untuk masa bakti 2014-2019. Pemilihan umum ini akhirnya dimenangi oleh pasangan Joko Widodo-Jusuf Kalla dengan memperoleh suara sebesar 53,15\% mengalahkan pasangan Prabowo SubiantoHatta Rajasa yang memperoleh suara sebesar 46,85\%. Pasangan calon Presiden Prabowo Subianto dan Hatta Rajasa didukung partai politik Gerindra, Golkar, PAN, PKS, PPP, PBB dan Demokrat, sedangkan pasangan Joko Widodo dan Muhammad Jusuf Kalla didukung gabungan partai politik PDIP, PKB, Nasdem, Hanura dan PKPI.

Pada pemilu Presiden tahun 2019 hanya diikuti oleh 2 pasangan yaitu pasangan Joko Widodo- Ma ruf Amin yang didukung oleh Partai PDIP, Golkar, PKB, Nasdem, PPP dan Hanura berhadapan dengan pasangan Prabowo Subianto-Sandiaga Uno yang didukung oleh Partai Gerindra, PKS, PAN dan Demokrat. Akhirnya pasangan Joko Widodo-Ma ruf Amin terpilih

27 Haris, S. (2014). Praktik Parlementer..., Op.Cit., h. 149-150.

28 Efendi, S. (2012). Sistem Pemerintahan Indonesia, Asthabrata, XI (1) : 46-59, h. 57

29 Marijan, K. (2011). Sistem Politik Indonesia Konsolidasi Demokrasi Pasca Orde-Baru, Jakarta: Kencana, h. 107.

$$
\text { 524|SASI Vo1. } 27 \text { No.4, Oktober - Desember } 2021
$$


menjadi Presiden dan Wakil Presiden RI periode 2019-2020.

Menurut penulis pola koalisi partai politik di Indonesia sangat fleksibel, tidak bersifat linear dan inkonsisten. Sebagai contoh partai politik yang sama dapat berseberangan dengan partai yang lain dalam memberikan dukungan untuk calon pemimpin nasional tetapi dapat berkoalisi dalam mendukung calon yang sama untuk pemimpin level daerah. Sebagai contoh seperti yang terjadi pada pemilu 2014 dimana terpolarisasinya partai-partai politik ke dalam dua kubu yakni kubu KMP dan KIH. Setelah berakhirnya kontestasi, idealnya partai-partai politik yang tergabung ke dalam KMP tetap bertahan dan menjadi kelompok oposisi agar semakin terciptanya pemerintahan yang kuat, tetapi realitanya hanya Gerindra dan PKS yang tetap bertahan, sedangkan Golkar, PAN dan PPP bergabung dengan partai pemerintah, sedangkan Demokrat mengambil sikap netral. Idealnya kalau partai politik tetap memegang teguh idealisme dalam berpartai, tentunya pola koalisi yang bersifat pragmatis tersebut tidak mudah untuk dilakukan walaupun kita sadari bahwa berbicara politik memang berbicara kepentingan.

Tabel.1

Hubungan Antara Sistem Multipartai, Partai Pendukung dan Partai Oposisi

\begin{tabular}{|c|c|c|c|c|}
\hline No & $\begin{array}{l}\text { Nama Presiden } \\
\text { ( Masa Jabatan) }\end{array}$ & Partai Pendukung & $\begin{array}{c}\text { Partai } \\
\text { Oposisi }\end{array}$ & Keterangan \\
\hline 1. & $\begin{array}{l}\text { KH. } \\
\text { Abdurrahman } \\
\text { Wahid } \\
(1999-2001)\end{array}$ & $\begin{array}{l}\text { Dikenal dengan } \\
\text { Koalisi Poros } \\
\text { Tengah yang } \\
\text { terdiri dari PAN, } \\
\text { PPP, PBB, Partai } \\
\text { Keadilan dan } \\
\text { partai-partai } \\
\text { Islam gurem } \\
\text { lainnya. }\end{array}$ & - & $\begin{array}{l}\text { Dimakzulkan sebelum } \\
\text { masa jabatan berakhir. } \\
\text { Proses pemakzulan juga } \\
\text { dilakukan oleh Koalisi } \\
\text { Poros Tengah yang } \\
\text { dipimpin oleh Prof. Dr. } \\
\text { Amin Rais selaku } \\
\text { pemimpin informal } \\
\text { Poros tengah. }\end{array}$ \\
\hline 2. & $\begin{array}{l}\text { Megawati } \\
\text { Soekarnoputri } \\
\text { (2001-2004) }\end{array}$ & PDIP & - & $\begin{array}{l}\text { Menggantikan posisi } \\
\text { Abdurrahman Wahid. } \\
\text { Pernah diupayakan hak } \\
\text { interpelasi oleh DPR } \\
\text { dalam kasus lenyapnya } \\
\text { Pulau Sipadan Ligitan, } \\
\text { kunjungannya ke Timor } \\
\text { Leste dan bantuan } \\
\text { sebesar } 30 \text { Miliar bagi } \\
\text { asrama TNI/Polri, } \\
\text { walaupun pada akhirnya } \\
\text { hak interpelasi tersebut } \\
\text { gagal dilakukan. }\end{array}$ \\
\hline 3. & $\begin{array}{l}\text { Susilo Bambang } \\
\text { Yudhoyono } \\
(2004-2009)\end{array}$ & $\begin{array}{l}\text { Demokrat, PKS, } \\
\text { PBB (Koalisi } \\
\text { Kerakyatan). } \\
\text { Dalam perjalanan } \\
\text { bergabung } \\
\text { Golkar, PPP, PAN } \\
\text { dan PKB. }\end{array}$ & PDIP & $\begin{array}{l}\text { Diawal pemerintahan, } \\
\text { didukung enam partai } \\
\text { minus Golkar. Golkar } \\
\text { yang dipimpin Akbar } \\
\text { Tandjung } \\
\text { PDIP bersama } \\
\text { Kebangsaan) menjadi } \\
\text { oposisi. Setelah Jusuf } \\
\text { Kalla (JK) menjadi } \\
\text { Ketum, Golkar berbalik }\end{array}$ \\
\hline
\end{tabular}




\begin{tabular}{|c|c|c|c|c|}
\hline & & & & $\begin{array}{l}\text { menjadi partai } \\
\text { pendukung pemerintah. }\end{array}$ \\
\hline 4. & $\begin{array}{l}\text { Susilo Bambang } \\
\text { Yudhoyono } \\
(2009-2014)\end{array}$ & $\begin{array}{l}\text { Partai Demokrat, } \\
\text { PKS, PAN, PPP, } \\
\text { PKB dan Golkar. }\end{array}$ & PDIP & $\begin{array}{l}\text { Adanya desakan untuk } \\
\text { mengeluarkan PKS } \\
\text { dari partai koalisi karena } \\
\text { menolak kenaikan } \\
\text { Bahan Bakar Minyak } \\
\text { bersubsidi, dianggap } \\
\text { bertentangan dengan } \\
\text { kebijakan partai koalisi }\end{array}$ \\
\hline 5. & $\begin{array}{l}\text { Joko Widodo } \\
\text { (2014-2019) }\end{array}$ & $\begin{array}{l}\text { PDIP, Hanura, } \\
\text { Nasdem, PKB, } \\
\text { PPP, Golkar, dan } \\
\text { PAN. }\end{array}$ & $\begin{array}{l}\text { Gerindra } \\
\text { dan PKS }\end{array}$ & $\begin{array}{l}\text { Golkar dan PAN } \\
\text { akhirnya bergabung di } \\
\text { pemerintahan Jokowi- } \\
\text { JK. } \\
\text { Partai Demokrat } \\
\text { mengambil posisi netral. }\end{array}$ \\
\hline 6. & $\begin{array}{l}\text { Joko Widodo } \\
(2019-2024)\end{array}$ & $\begin{array}{l}\text { PDIP, Golkar, } \\
\text { PKB, Nasdem, } \\
\text { PPP, Hanura, } \\
\text { Gerindra }\end{array}$ & $\begin{array}{l}\text { PKS, } \\
\text { Demokrat, } \\
\text { PAN }\end{array}$ & $\begin{array}{l}\text { Partai Gerindra masuk } \\
\text { ke pemerintahan setelah } \\
\text { pemilu Presiden }\end{array}$ \\
\hline
\end{tabular}

\section{Data diolah dari berbagai sumber}

Menurut penulis ketika peserta kontestasi calon Presiden hanya terdiri dari dua kubu (head to head), polarisasi kekuatan partai politik semakin kuat. Beda halnya jika calon Presiden lebih dari dua pasangan calon karena partai dari pasangan calon yang lain dapat menetralisir polarisasi tersebut. Perseteruan antara KIH dan KMP di gedung DPR pasca pelantikan Presiden terpilih sebenarnya tidak perlu terjadi karena kontestasi sudah berakhir. Diharapkan kepada para politisi lebih menunjukkan sikap kedewasaan dalam berpolitik, bukan sebaliknya mempertontonkan syahwat politik dihadapan rakyat, dalam satu periode kepemimpinan, efektifitas Presiden dalam menjalankan pemerintahan hanya berlangsung tiga tahun karena dua tahun berikutnya merupakan tahun politik. Perebutan kekuasaan yang dipertontonkan oleh kedua kubu menunjukkan eksistensi partai politik bukan mewakili kepentingan rakyat, tetapi mewakili kepentingan pribadi dan golongannya. Seharusnya kepada Presiden terpilih dan partai politik yang mendukungnya diberikan kesempatan untuk menjalankan pemerintahan dan kubu partai politik yang kalah mengambil sikap sebagai oposisi agar pemerintahan berjalan dengan baik dalam rangka mensejahterakan rakyat.

\section{Sistem Kepartaian Yang Ideal Dalam Sistem Pemerintahan Presidensial di Indonesia}

Maurice Duverger menggolongkan sistem kepartaian menjadi tiga, yaitu (1) Sistem partai tunggal, (2) Sistem dwipartai, dan (3) Sistem multipartai. ${ }^{30}$

a) Sistem Partai Tunggal

Pola partai tunggal terdapat di beberapa negara: Afrika, China, dan Kuba, sedangkan dalam masa jayanya Uni Soviet dan beberapa negara Eropa Timur termasuk dalam kategori ini. Suasana kepartaian dinamakan non-kompetitif karena semua partai harus menerima pimpinan dari partai yang dominan, dan tidak dibenarkan bersaing dengannya. ${ }^{31}$ Terutama di negaranegara yang baru lepas dari kolonialisme ada kecendrungan kuat untuk memakai pola sistem partai tunggal karena pimpinan (sering seorang pemimpin yang kharismatik) dihadapkan dengan masalah bagaimana mengintegrasikan berbagai golongan, daerah, serta suku bangsa

30 Labolo, M. (2013). Memahami Ilmu Pemerintahan Suatu Kajian, Teori, Konsep dan Pengembangannya, Jakarta: Rajawali Pers, h. 32.

31 Budiardjo, M. (2008). Dasar -Dasar Ilmu Politik Edisi Revisi, Jakarta : Gramedia, h. 415 
yang berbeda corak sosial serta pandangan hidupnya. Dikhawatirkan bahwa bila keanekaragaman sosial dan budaya ini tidak diatur dengan baik akan terjadi gejolak-gejolak sosial politik yang menghambat usaha pembangunan.

Negara yang paling berhasil dalam menyingkirkan partai-partai lain ialah Uni Soviet pada masa jayanya. Partai Komunis Uni Soviet bekerja dalam suasana yang non-kompetitif, tidak ada partai lain yang diperbolehkan bersaing, oposisi dianggap sebagai pengkhianatan. Di Indonesia pada tahun 1945 ada usaha mendirikan partai-tunggal sesuai dengan pemikiran yang pada saat itu banyak dianut di negara-negara yang baru melepaskan diri dari rezim kolonial. ${ }^{32}$ Pandangan penulisusaha mendirikan partai tunggal yang dimaknai semua partai yang ada tunduk di bawah kekuasaan dan kendali pemerintah yakni Soekarno tidak seharusnya dilakukan karena disamping tidak membuka ruang kompetisi yang sehat dan akan melahirkan pemimpin yang berwajah otoriter. Salah satu eksistensi partai politik adalah wadah untuk mencetak pemimpin-pemimpin bangsa.

\section{b) Sistem Dwipartai}

Dalam berbagai kepustakaan, pengertian sistem dwipartai biasanya diartikan adanya dua partai atau adanya beberapa partai tetapi dengan peran dominan dari dua partai. Sedikit negara yang pada dewasa ini memiliki sistem dwipartai, kecuali Inggris, Amerika Serikat dan Filipina, dan oleh Maurice Duverger malahan dikatakan bahwa sistem ini adalah khas Anglo Saxon. Kendati demikian, khusus dalam kasus Inggris, sistem dwipartai yang selama ini dianut Inggris telah mulai terkikis.

Di Inggris saat ini, di samping dua partai yang ada, yaitu Partai Buruh dan Partai Konservatif hadir pula partai-partai politik lain seperti Partai Liberal Demokrat. Pengaruh partai demikian memang terbatas jika dilihat dari perolehan suaranya di parlemen, hanya saja ia menjadi signifikan dalam berbagai pengambilan kebijakan pada saat terjadi perbedaan perolehan suara yang cukup tipis antara dua partai besar tersebut. ${ }^{33}$

Penulis berpandangan penerapan sistem dwipartai untuk Indonesia sulit untuk diterapkan disamping karena bangsa Indonesia bersifat heterogen, baik dari suku, agama, ras, budaya dan lain-lain, di tambah lagi kedewasaan berpolitik dan berdemokrasi, baik untuk level elit partai, terlebih lagi untuk kalangan grassroot belum siap untuk itu.Pengalaman pemilihan kepala daerah selama ini, di mana friksi-friksi antara pendukung calon sangat tinggi bahkan sampai berakibat menelan korban jiwa. Jika penerapan sistem dwipartai ini dalam konteks pemilihan Presiden, tentunya frekuensi terjadinya friksi tersebut cenderung lebih tinggi karena para pendukung terpolarisasi ke dalam dua kutub yang saling berseberangan di mana tidak ada partai ketiga untuk dapat menetralisir keadaan ini. Hal ini tentunya akan berimplikasi negatif terhadap proses demokrasi.

Pada pelaksanaan pemilu legislatif tahun 1999 yang diikuti 48 partai politik, lima besar peraih suara terbanyak adalah sebagai berikut : PDIP (33,74\%), Golkar (22,44\%), PKB $(12,61 \%)$, PPP(10,71\%), PAN $(7,12 \%)$, sisanya antara nol sampai satu persen. Pada pelaksanaan pemilu legislatif tahun 2004, partai peserta pemilu berjumlah 24 partai dengan perolehan suara sebagai berikut : Golkar (21,58\%), PDI-P (18,53\%), PKB (10,57\%), PPP (8,15\%), Demokrat (7,45\%), PKS (7,34\%), PAN (6,44\%), PBB (2,62\%), PBR (2,44\%), PDS $(2,13 \%)$ dan PKPB $(2,11 \%)$, partai lainnya berada di kisaran nol sampai satu pesen. Pemilihan umum anggota DPR 2009 diikuti oleh 38 partai politik dengan perolehan suara sebagai berikut : Demokrat (20,85\%), Golkar (14,45\%), PDIP (14,03\%), PKS (7,88\%), PAN (6,01\%), PPP

32 Suparto. (2017). Pengujian UU No. 27 Tahun 2009 dan UU No. 17 Tahun 2014 Tentang MPR, DPR, DPD \& DPRD (MD3) Sebagai Upaya DPD Untuk Mengembalikan Kewenangan Konstitusionalnya, UIR Law Review, 1 (1) : 13-24, h. 21, DOI : https ://doi.org/10.25299/url.2017.1.01.150

33 Karsayuda, M. R. (2015). Partai Politik Lokal Untuk Indonesia Kajian Yuridis Ketatanegaraan Pembentukan Partai Politik Lokal di Indonesia Sebagai Negara Kesatuan, Jakarta : Rajawali Pers, h. 118. 
(5,32\%), PKB (4,94\%), Gerindra (4,46\%) dan Hanura (3,77\%), partai lainnya berada di kisaran nol sampai satu persen. Pemilihan umum anggota DPR 2014 diikuti oleh 12 partai politik dengan perolehan suara sebagai berikut : PDIP (18,95\%), Gokar $(14,75 \%)$, Gerindra(11,81\%), Demokrat (10,19\%), PKB (9,04\%), PAN (7,59\%), PKS (6,79\%), Nasdem (6,72\%), PPP (6,53\%), Hanura (5,26\%), PBB (1,46\%) dan PKPI (0,91\%). Pemilihan umum anggota DPR 2019 diikuti oleh 16 partai politik dengan perolehan suara sebagai berikut : PDIP $(19,33 \%)$, Gerindra(12,57\%), Golkar (12,31\%), PKB (9,67\%), Nasdem (9,05\%), PKS (8,21\%), Demokrat $(7,77 \%)$, PAN $(7,59 \%),(6,72 \%)$, PPP $(4,52 \%)$, Perindo $(2,67 \%)$, Berkarya $(2,09 \%)$, PSI $(1,89 \%)$, Hanura $(1,54 \%)$, PBB $(0,79 \% \%)$, Garuda $(0,50 \%)$, dan PKPI $(0,22 \%)$. Dari pemaparan prosentase perolehan suara pemilihan umum anggota DPR dari tahun 1999, 2004, 2009, 2014 dan 2019 maka dapat disajikan dalam bentuk tabel seperti di bawah ini.

Tabel. 2

Electoral Threshold atau Parliamentary Threshold dan Partai Politik yang lulus dalam Pemilihan Umum Legislatif.

\begin{tabular}{cccccc} 
No & Pemilu & UU Pemilu & $\begin{array}{c}\text { ET/PT } \\
(\%)\end{array}$ & $\begin{array}{c}\text { Jumlah Partai } \\
\text { Yang Lolos }\end{array}$ & Ket \\
\hline 1. & 1999 & UU No.3 Tahun 1999 & 2 & 5 & ET \\
\hline 2. & 2004 & UU No.12 Tahun 2003 & 3 & 7 & ET \\
\hline 3. & 2009 & UU No.10 Tahun 2008 & 3 & 9 & PT \\
\hline 4. & 2014 & UU No.8 Tahun 2012 & 3,5 & 10 & PT \\
\hline 5. & 2019 & UU No.7 Tahun 2017 & 4 & 9 & PT \\
\hline
\end{tabular}

Jika penerapan angka Electoral Threshold (ET) atau Parliamentary Threshold (PT) sebesar $8 \%$ dalam rangka penyederhanaan partaipolitik maka partai politik yang akan lolos pada pemilihan umum legislatif dari tahun 1999, 2004, 2009, 2014 dan 2019 dapat dilihat pada tabel di bawah ini.

Tabel.3

Simulasi Jika Angka Electoral Threshold atau Parliamentary Threshold 8\%.

\begin{tabular}{cccc}
\hline No & Pemilu & UU Pemilu & Jumlah Partai Yang Lolos \\
\hline 1. & 1999 & UU No. 3 Tahun 1999 & 4 \\
\hline 2. & 2004 & UU No.12 Tahun 2003 & 4 \\
\hline 3. & 2009 & UU No.10 Tahun 2008 & 3 \\
\hline 4. & 2014 & UU No. 8 Tahun 2012 & 5 \\
\hline 5. & 2019 & UU No. 7 Tahun 2017 & 6 \\
\hline
\end{tabular}

Bachtiar Effendy menilai untuk sistem pemerintahan presidensial idealnya jumlah partai politik peserta pemilu hanya sebanyak empat atau lima. Keadaan tersebut tidak sesuai dengan kondisi di Indonesia yang menerapkan sistem presidensial, namun jumlah partai politik peserta pemilu mencapai 12 untuk skala nasional, ditambah tiga partai lokal di Provinsi Aceh. Di manamana itu kalau kita mau menerapkan sistem presidensial, kalau mau efektif itu jumlah partainya sedikit. Aturan ini yang tidak koheren, kita menerapkan presidensial tetapi aturan kepartaian sangat liberal, ujarnya. ${ }^{34}$ Jumlah partai politik (parpol) yang ideal di Indonesia adalah lima sampai enam partai. Sistem multipartai yang dianut Indonesia memang memberikan kesempatan bermunculan parpol-parpol baru tetapi tidak memberikan kemajuan dalam politik dan kesejahteraan. Tidak ada masalah dengan banyaknya parpol, namun yang lebih masuk akal itu berjumlah lima atau enam saja, sembilan parpol seperti DPR juga baik, ungkap pengamat

\footnotetext{
${ }^{34}$ Suparto (2017). Perbedaan Tafsir Mahkamah Konstitusi Dalam Memutus Perkara Pemilihan Umum Serentak, Yudisial, 10 (1) : 1-16, DOI : http ://dx.doi.org/10.29123/jy.v10i1.39
} 
politik Eef Saefulloh Fatah. ${ }^{35}$

Menurut penulis sistem kepartaian untuk Indonesia saat ini tidak mesti harus kembali kepada sistem kepartaian di era Presiden Soekarno, tidak pula harus mengadopsi sistem kepartaian model Amerika Serikat atau Inggris dengan sistem dwipartai atau harus kembali dengan pola kepartaian pada era Orde Baru dengan dua partai politik dan satu golongan kekaryaan. Indonesia sebaiknya tetap mempertahankan sistem multipartai sesuai dengan tuntutan reformasi yang salah satunya adalah memberikan kebebasan berserikat dan berkumpul tetapi dengan sistem kepartaian yang lebih sederhana. Pada era Orde Lama dan Orde Baru, kebebasan berserikat dan berkumpul memang cenderung dibungkam. Tetapi tidak mesti pula euforia dan semangat reformasi itu sendiri berimplikasi pada lahirnya partai politik yang tidak terkendali. Proses demokrasi sebaiknya tidak hanya dilihat dari aspek kuantitas tetapi yang lebih substantiv adalah dari aspek kualitas. Pemilu legislatif tahun 2014 melahirkan sepuluh partai yang di Senayan dirasakan masih terlalu banyak. Untuk ke depannya, partai politik di Indonesia dapat lebih disederhanakan lagi. Sejak penyelenggaraan pemilihan umum Tahun 1999 dan dilanjutkan di Tahun 2004, pembentuk undang-undang telah mempunyai legal policy (kebijakan hukum) dalam pengaturan partai politik, yaitu penyederhanaan partai politik, melalui pengurangan jumlah peserta pemilihan umum (melalui electoral threshold) dan kemudian berubah (sejak Pemilihan Umum Tahun 2009) menjadi pengurangan jumlah partai politik yang boleh duduk di parlemen (parliamentary threshold). ${ }^{36}$

Pendapat Penulis, langkah yang harus dilakukan agar sistem multipartai berjalan ideal jika diterapkan dengan sistem presidensial adalah dengan langkah menaikkan angka parliamentary threshold karena parliamentary threshold diperlukan untuk pembentukan fraksi di parlemen. Dalam pemilu legislative yang terakhir tahun 2019 angka parliamentary threshold hanya $4 \%$ tidak cukup signifikan dalam upaya menciptakan sistem presidensial yang ideal jika dipadukan dengan pola multipartai. Ideal di sini dimaknai sistem presidensial yang kuat dan stabil bila dipadukan dengan sistem multipartai. Parliamentary threshold memangtermasuk salah satu isu krusial selain dari presidential threshold dan tiga isu lainnya, dimana tarik ulur dan proses bargaining politik pasti tidak dapat terhindarkan karena menyangkut nasib partaipartai kecil dan partai-partai baru. Jika para stakeholders dalam hal ini pihak legislatif dan eksekutif selaku institusi pembuat UU berkomitmen untuk menciptakan pemerintahan yang ideal dimaksud, maka menaikkan angka parliamentary threshold yang menurut penulis besarannya $8 \%$ merupakan salah satu solusi yang terbaik karena dalam politik keseharian Presiden berhadapan dengan partai politik. Harus diakui bahwa dengan menaikkan angka parliamentary threshold terlalu tinggi dapat berimplikasi terhadap banyaknya suara pemilih yang terbuang dan dianggap tidak representatif karena Indonesia adalah negara yang luas dan heterogen baik dari suku, agama dan lain-lain. Politik adalah pilihan, menaikkan angka parliamentary threshold merupakan langkah yang tepat.Jika angka parliamentary threshold ditinggikan secara otomatis jumlah partai politik yang duduk di parlemen dapat diminimalisir, dengan minimnya partai politik di parlemen, tentunya Presiden akan lebih mudah mengendalikan parlemen dan diharapkan dapat terbentuk pola koalisi yang permanen sehingga dapat menciptakan sistem presidensial dengan multipartai yang kuat dan stabil yang diharapkan.

\section{PEN U T U P}

Sistem pemerintahan presidensial dengan banyak partai (multy party system) seperti yang diterapkan di Indonesia, persoalan akan muncul kalau tidak ada partai politik yang memenangkan pemilihan umum dengan suara mayoritas mutlak. Persoalan lain yang merupakan dampak dari kombinasi presidensialisme dan sistem multipartai adalah lemahnya

\footnotetext{
35 Isra, S. (2013). Hubungan Presiden dan DPR, Konstitusi, 10 (3) : 399-416, h. 412

36 Abadi, H. \& M. Sakdan, F. (2013). Mahkamah Konstitusi Dan Pencegahan Perampasan Kekuasaan Oleh Partai Besar, Mahkamah, 5 (1) : 1-8, h. 3.
}

$$
\text { 529|SASI Vo1. } 27 \text { No.4, Oktober - Desember } 2021
$$


disiplin partai-partai dalam mempertahankan sikap dan prinsip politik mereka. Dengan sistem multipartai, Presiden harus membangun koalisi dengan sejumlah partai politik di DPR. Keharusan itu seperti menjadi keniscayaan jika Presiden berasal dari kekuatan minoritas di DPR. Minoritas artinya Presiden yang terpilih dalam pemilu tetapi kekuatan partai pengusungnya di parlemen tidak mencapai angka lima puluh persen lebih sehingga tidak dapat menguasai parlemen. Salah satu faktor penyebab dari sistem multipartai adalah bahwa keanekaragaman budaya politik suatu masyarakat yang mendorong pilihan ke arah sistem multipartai. Pola multipartai lebih sesuai dengan pluralitas budaya dan politik dari pada pola dwipartai. Sejak penyelenggaraan pemilihan umum tahun 1999 dan dilanjutkan di tahun 2004, pembentuk undang-undang telah mempunyai legal policy (kebijakan hukum) dalam pengaturan partai politik, yaitu penyederhanaan partai politik, melalui pengurangan jumlah peserta pemilihan umum melalui electoral threshold dan kemudian berubah (sejak pemilihan umum tahun 2009) menjadi pengurangan jumlah partai politik yang boleh duduk di parlemen (parliamentary threshold). Namun demikian cara tersebut belum berhasil karena partai politik yang duduk di parlemen masih relativ banyak.

\section{DAFTAR PUSTAKA}

\section{Jurnal}

[1] Abadi, H. (2011). Perubahan Konstitusi dan Implikasinya Pada Politik Hukum Kepartaian di Indonesia, Mahkamah, 3 (2) : 12-24.

[2] Abadi, H. \& M. Sakdan, F. (2013). Mahkamah Konstitusi Dan Pencegahan Perampasan Kekuasaan Oleh Partai Besar, Mahkamah, 5 (1) : 1-8.

[3] Abadi, H. (2014). Presidential Threshold Sebagai Instrumen Proteksi, Mahkamah, 6 (1): 29-36.

[4] Al Arif, M. Y. (2015). Anomali Sistem Pemerintahan Presidensial Pasca Amandemen UUD 1945, Ius Quia Ius Tum, 22 (2) : 238-254, h. 250, DOI : 10.20885/iustum.vol22.iss2.art4.

[5] Arman, Z. (2018). Tinjauan Terhadap Sistem Multi Partai dalam Sistem Pemerintahan Presidensial di Indonesia Pada Era Reformasi, Cahaya Keadilan, 6 (1) : 23-40, h. 35, DOI: https : //doi.org/10.33884/jck.v6i1.875.

[6] Busroh, F.F. (2017). Reformulasi Penetapan Electoral Threshold Dalam Sistem Kepartaian di Indonesia, Lex Librum, 3 (2) : 513-524, h. 520, DOI : http : //doi.org/10.5281/zenodo.1257770

[7] Chaidir, E. \& Suparto, (2017). Implikasi Putusan Mahkamah Konstitusi Tentang Pemilu Serentak Terhadap Pencalonan Presiden dan Wakil Presiden Pada Pemilihan Umum Tahun 2019, UIR Law Review, 1 (1): 1-12, DOI: https://doi.org/10.25299/url.2017.1.01.561.

[8] Efendi, S. (2012). Sistem Pemerintahan Indonesia, Asthabrata, XI (1) : 46-59.

[9] Efriza, (2019). Penguatan Sistem Presidensial Dalam Pemilu Serentak 2019, Jurnal Penelitian Politik, 16 (1) : 1-15.

[10] Isra, S. (2013). Hubungan Presiden dan DPR, Konstitusi, 10 (3) : 399-416.

[11]Partono (2008). Sistem Multi Partai Presidensial dan Persoalan Efektifitas Pemerintah, Legislasi Indonesia, 5 (1) : 13-28.

[12]Romli, L. (2011). Reformasi Partai Politik dan Sistem Kepartaian di Indonesia, Politica, 2 (2): 199-220.

[13] Rantau, M.I. (2019). Penguatan Sistem Presidensial di Indonesia; Analisis Terhadap UU No. 7 Tahun 2017 Tentang Pemilihan Umum, Pelita, 19 (2) : 181-193.

[14] Saraswati, R. (2012). Desain Sistem Pemerintahan Presidensial Yang Efektif, Masalah Masalah Hukum, 41 (1) : 137-143, h. 140, DOI : 10.14710/mmh.41.1.2012.137-143.

[15] Suparto. (2017). Pengujian UU No. 27 Tahun 2009 dan UU No. 17 Tahun 2014 Tentang MPR, DPR, DPD \& DPRD (MD3) Sebagai Upaya DPD Untuk Mengembalikan Kewenangan Konstitusionalnya, UIR Law Review, 1 (1) : 13-24, h. 21, DOI : https ://doi.org/10.25299/url.2017.1.01.150. 
[16] Suparto (2017). Perbedaan Tafsir Mahkamah Konstitusi Dalam Memutus Perkara Pemilihan Umum Serentak, Yudisial, 10 (1): 1-16, http://dx.doi.org/10.29123/jy.v10i1.39.

\section{Buku}

[17]Budiardjo, M. (2008). Dasar-Dasar Ilmu Politik Edisi Revisi, Jakarta: Gramedia.

[18] Chaidir, E. \& Fahmi, S. (2010). Hukum Perbandingan Konstitusi, Yogyakarta: Total Media.

[19]Haris, S. (2014). Praktik Parlementer Demokrasi Presidensial Indonesia, Yogyakarta: Andi Offset.

[20] Isra, S. (2010). Pergeseran Fungsi Legislasi; Menguatnya Model Legislasi Parlementer dalam Sistem Presidensial Indonesia, Jakarta: Rajawali Pers.

[21]Karsayuda, M. R. (2015). Partai Politik Lokal Untuk Indonesia Kajian Yuridis Ketatanegaraan Pembentukan Partai Politik Lokal di Indonesia Sebagai Negara Kesatuan”, Jakarta: Rajawali Pers.

[22]Labolo, M. (2013). Memahami Ilmu Pemerintahan Suatu Kajian, Teori, Konsep dan Pengembangannya, Jakarta: Rajawali Pers.

[23] Marijan, K. (2011). Sistem Politik Indonesia Konsolidasi Demokrasi Pasca Orde-Baru, Jakarta: Kencana.

[24] Sanit, A. (2012). Sistem Politik Indonesia, Jakarta: Rajawali Pers.

[25] Siahaan, P. (2012). Politik Hukum Pembentukan Undang-Undang Pasca Amandemen UUD 1945, Jakarta: Konstitusi Press.

[26] Yudha AR, H. (2010). Presidensialisme Setengah Hati Dari Dilema Ke Kompromi, Jakarta: Gramedia Pustaka Utama. 